\title{
The effect of leadership style and job motivation on the performance of teachers
}

\author{
Ramsiah Hiranah ${ }^{1}$, Happy Fitria ${ }^{2}$, Achmad Wahidy $^{2}$ \\ ${ }^{1}$ Madrasah Aliyah Negeri 1 Musi Banyuasin, Indonesia \\ ${ }^{2}$ Universitas PGRI Palembang, Indonesia
}

\begin{tabular}{l}
\hline Article Info \\
\hline Article history: \\
Received Jul $16^{\text {th }}, 2021$ \\
Revised Aug $9^{\text {th }}, 2021$ \\
Accepted Aug $30^{\text {th }}, 2021$ \\
\hline
\end{tabular}

\section{Keyword:}

Main style of leadership Encouragement for work Teacher success

\begin{abstract}
The main objective of this study is to define and explain the impact on teacher performance of the leadership style of the head of the Madrasah and job motivation simultaneously. Quantitative analysis is this form of study performed in this study. Techniques for qualitative data collection, questionnaires and documentation.." Using different linear regression models, it was analyzed. With the help of the version 21 SPSS program. A saturated sampling technique was used in this analysis, where all 49 respondents were tested. From the following conclusions, the findings of data processing and interpretation are drawn: The principal's leadership style has a positive and important effect on the performance of teachers. Motivation for work has a positive and meaningful influence on the success of teachers. At the same time, the leadership style of madrasah principals and job motivation have a profound influence on teacher performance.
\end{abstract}

C 2021 The Authors. Published by IICET.

This is an open access article under the CC BY-NC-SA license

(https://creativecommons.org/licenses/by-nc-sa/4.0

\section{Corresponding Author:}

Hiranah, R.,

Madrasah Aliyah Negeri 1 Musi Banyuasin, Indonesia

Email: ramsiah2019@gmail.com

\section{Introduction}

Schools are formal educational institutions, to carry out all activities of school principals and educators in carrying Job encouragement is another variable that can boost the career of an instructor. If he has good motivation, a teacher will work professionally. Employees/teachers with high motivation will usually perform their duties with passion and accountability, because these acts have certain motivations behind them. There is a positive connection between encouragement for success and job accomplishment that will have an impact on the career growth of the teacher. This means that high performance is accomplished by leaders, managers and workers with high motivation for accomplishment, and vice versa, poor performance is due to low motivation for work.To ensure that the teacher's profession will also have an impact. In helping teachers to try to improve their subordinates' careers so that they can not only stop at that time, the position of the principal here is very critical. Furthermore, it takes every individual teacher's willingness to inspire himself so that he can get used to publishing scientific works or doing them so that it can be a good value for his career. [1]"A type of leader is someone who can impact others and who has managerial power. Whereas administration isThe process of leading the group and influencing the group to accomplish a goal [2]. With its research title, The Impact of Principal Leadership, Job Motivation, and School Culture on Teacher Performance, according to research by Sri Setiyati. The conditions that a leader must meet in order to be successful in effectively leading the organization are as follows:A) Possessing ample intellect to be able to think about and find solutions to any issues that occur correctly and wisely.(b) Have healthy feelings or are not easily affected by different 
atmospheric changes and can differentiate between personal problems, domestic problems and organizational problems. (c) Have intelligence in communicating with others and can make subordinates feel at home, comfortable, and happy at work. D) To have the expertise to wisely coordinate and mobilize subordinates in the accomplishment of organizational objectives and to know specifically when and to whom duty and authority will be transferred [3]."

The findings of the author in MAN 1 Muba, although the completeness of the facilities, many of which have been fulfilled, such as a library, is not ideal for the school when seen from the organizational performance. Schools that already have full infrastructure, but are not motivated by these facilities, would not give any significance to the evaluation of the school, because school infrastructure, such as: libraries can be used as reading places for students and teachers, but the books are not merely display content, which is still neatly packed, is never touched.Furthermore, there are only 10 learning media facilities, such as infocus, while at MAN 1 Muba there are 21 study classes, which alternately cause the use of in-focus. Thus, it is expected that student performance will be able to increase through the empowerment of these infrastructures. Moreover, it was discovered from the author's preliminary findings that about 10 percent of the current MAN 1 Muba infrastructure could no longer be empowered because some of the physical conditions were weakened and no longer fit for use. "MAN 1 Muba's attempts to develop the educational system have been carried out through partnering with student parents / guardians and the private sector. Some educational facilities were obtained from this partnership from donations from alumni and some from Sekayu City entrepreneurs.

For this purpose, it is important to have a principal who is able and understands the management of school-based education facilities and infrastructure. This is in accordance with the policies outlined by the Ministry of Education on the competency requirements that the Principal must have, one of which is the managerial competence factor. In this scenario, in order to maximize utilization, the principal must have the capacity to handle school facilities and infrastructure.

\section{Theoretical foundation}

\section{Teacher Success Description}

[5] Success is the work done by a person in an organization that is in line with the authority and duty in an attempt to achieve the objectives to be achieved. A teacher shall prepare learning, carry out a quality learning process, review and evaluate learning outcomes and follow-up on the results of the assessment as an attempt to enhance the quality of learning, as provided for in Article 20 of the Law of the Republic of Indonesia No 14 of 2005 on Teacher Professional Duties. [2] Rreally decide the success of the education of a nation. That the teacher is very determined by the progress of the school reform, is because the teacher is the leader of learning, facilitator, and as the hub of learning initiatives. Teachers must therefore always grow individually, not on the initiative of the principal and supervisor alone. Teacher quality is expected in the world of education. One of which is the standard of the performance of teachers. The importance of the performance of teachers is set out in Regulation No 16 of 2007 of the Minister of National Education of the Republic of Indonesia on Academic Qualification Levels and Teacher Competencies. It was clarified that from four key competencies, namely Pedagogic, Personality, Social, and Professional Competencies, Teacher Competency Requirements are established in their entirety. The fourth competency incorporated in the success of teachers

\section{Factors influencing work by teachers}

Factors that come from outside of an instructor are external factors. External factors that can affect teacher performance, namely, [4], are:

1. pay, which is a form of appreciation given to a teacher for job performance. ;

2. Equipment and resources are both devices and services that are used specifically in the educational process in classrooms. ;

3. the physical working environment, including lighting, coloring, air, cleanliness, noise, and protection. ; and

4. leadership that can be seen from the management style of the principal. The style of leadership influences the performance of teachers to improve job efficiency in order to achieve goals.

\section{Leadership Description}

The word "leader" comes from leader, and the word "leadership" comes from leadership. The leader is a resultoriented individual and if the leader decides what he wants, the results will be obtained. [6] a leader is an individual with a certain dominance, so that he has the power and authority to move others to make joint efforts to accomplish certain objectives. 
Leadership means the capacity and readiness that a person must be able to influence, inspire, invite, guide, organize, direct, and if necessary force individuals or groups to embrace this influence and then do something that can help achieve a certain objective that has been set, according to the University of Indonesia Educational Administration Lecturer Team (2014).

1. Leadership Principal.

When there is no chief, an educational institution will not function well. A school's progress can be impacted by the style of leadership of the principal as a guiding force for efforts to accomplish an objective. In general, educational leadership, according to [7] is the capacity and readiness an individual has to influence, inspire, invite, direct, organize, and force others to be able to receive influence from others.

2. The' Principal Leadership' style

The style of leadership is a tool used by leaders to impact their followers. Each leader has a distinctive and distinct style of leadership from one another. [8] demonstrate that the style of leadership is a complete pattern of the behavior of a leader, both visible and invisible to his subordinates. Meanwhile, [9] An individual's behavioral norm is used when that person affects the actions of others as seen. [9] The leadership style is a common pattern of leadership actions when its subordinates are affected. It can be inferred from many descriptions of leadership style above that leadership style is a common action used by leaders to impact their subordinates to accomplish organizational objectives. Every leader has unique features, behaviors, and personality of his own. This will influence the leader's style or actions. " Leadership style is a detailed pattern of a leader's behaviour, both visible and invisible to subordinates, the characteristics and attitudes that underlie one's behavior, [2]. The style of leadership will directly display the confidence of a leader in the skills of his subordinates. This means that leadership style is action and technique, as a result of a mixture of the ideology, talents, characteristics, behaviors, which are also applied by a leader as he attempts to control the performance of his subordinates.

\section{Motivation Description}

Motivation is described as an initiative that helps you to do something. In order to accomplish an objective, a motive can be interpreted as a guiding force from within and within the subject to carry out such activities. It is possible to view even a motive as an internal state (preparedness). Motivation can be defined as a driving force that has become involved, beginning from the word 'motive'. At certain moments, the motive becomes active, especially when the need to achieve objectives is felt or urgent. In order to accomplish those goals, motivation has an essential function in any individual organization or group of people who collaborate. [2]; 5). It is possible to understand the variations in actions between one another by observing the different motives and influences that affect them. [10] Motivation is the force, drive, need, enthusiasm, strain, or psychological mechanism that encourages an individual or group of people to accomplish certain achievements according to what they want, according to [11].

1. Model of Motivation Strategy in Organisation

One part of the principle of motivation is achievement motivation. [8], there are several models of encouragement that school principals may use as an approach to teachers in relation to improving results, including:(1) The conventional model, that is, the sort of effort made by the principal to make it enjoyable for teachers to carry out boring jobs. (2) The model of human relationships, namely the principal, highlights how to inspire teachers to improve job satisfaction by understanding the social needs of teachers. (3) Not only does the model of human resources, namely the principal, have the role of supplying teachers with salaries only, but the principal must also create a sense of belonging in the achievement of organizational objectives.

2. Leader's attempts to inspire teachers

The leader is not only quiet and commands members of the group in order to accomplish results in an operation, but it is important to provide the leader with encouragement. The leader must know the best ways of enhancing the success of the members of his party. 
There are many ways in which leaders can improve motivation, [12], and these strategies can be carried out by school principals, including:

a. Respect, that is to say, on the basis of achievement, rank and experience, a principal should give respect and gratitude equally to teachers.

b. Information, namely a principal, often provides information, especially about a job and how to do it, related to organizational activities. Knowledge in an educational and convincing way should be provided.

c. Conduct, that is, an indication of the behavior the teacher expects, would be given by a successful principal.

d. Punishment, that is, apart from other participants, the principal should give punishment to the guilty teacher. The penalty given should be capable of making the instructor even better.

e. Orders, that is to say, a successful principal would implicitly send orders. The principal gave orders such as welcoming and, if it was started with an example, even better.

f. Feelings, including the interactions between the principal and the teacher, should be carried out in soft words, accompanied by a sense of friendship and a sense of engagement that makes them feel secure.

What is essential in enhancing teacher performance is the principal's leadership role. Each leader is responsible for guiding teachers to do a good job, and the principal often offers patiently conducted understanding and examples. As a chief, the principal must have the capacity to encourage the discipline and motivation of employees [9], including:

a. Evolution of Discipline

To instill respect, both for individuals and for others, discipline is essential. In this scenario, the leader must be able to support workers to be able to establish a routine of acceptable behavioral expectations.

b. Inspiration generation

Each worker has his own qualities, special features, and is distinct from each other. In any operation, motivation is an essential factor. Motivation is a motivation that is used to do something to fulfill needs, both from inside and outside of an individual. Motivation is used to push influences that can improve the efficacy of success.

3. Awards

Awards are used in the world of work as part of the attempts made to raise employee productivity at work. If it is openly linked to employee success, the reward granted by the leader would be meaningful, so that every employee has the same opportunity to achieve it.

From the understanding of the experts above, as a leader, excitement is required to give encouragement to employees. Employees feel the need for love and when the leader offers motivation, a sense of self-worth is considered. This will allow workers to have good relationships and deep emotional connections.

\section{Method}

A quantitative approach to the form of causal analysis is used in this research. Techniques for qualitative data collection, questionnaires and documentation.Analysed using multiple linear regression formulas. This analysis uses a saturated sampling methodology with the aid of the SPSS version 21 software, where all respondents, amounting to 49 participants, will be tested.

\section{Results and Discussions}

\section{The impact of Madrasah principals' leadership style on teacher performance}

The regression coefficient for the leadership style variable of madrasah principals is positive based on the results of multiple regression analysis, suggesting that the impact of the leadership style of the headmaster on teacher performance is a positive effect, which indicates that each unit will increase the leadership style score of the headmaster, accompanied by increased performance. Each time there is a decrease in the score of the principal's leadership style, teachers and vice versa will be followed by a decrease in teacher performance. 


\section{Impact of job motivation on the performance of teachers}

The results of multiple regression analysis indicate that the regression coefficient for the work motivation variable is positive, suggesting that the impact of work motivation on teacher performance is a positive effect, implying that any time there is an increase in work motivation score, an increase in teacher performance will follow and vice versa. The job motivation unit score will be followed by a reduction in teacher results.

\section{The effect of Madrasah Principals' leadership style and job motivation on teacher performance}

The simultaneous test results indicate that the presence of the principal's correct leadership style in leading the organization and good motivation for work would have a good effect on the execution of all teacher efficiency. The results of the simultaneous test show that the value of Fcount is greater than Ftable and that it is less than 0.055 with a reasonable probability of 0000 (significance level). From the R-square, which is $37.2 \%$, the sum of simultaneous contribution of the leadership style of the headmaster and job motivation to teacher success can be seen

\section{Conclusions}

The conclusions are: 1) A conclusion can be drawn on the basis of the findings of the study and discussion: The leadership style of the head of the madrasah has a positive and important influence on the success of teachers in MAN 1 MusiBanyuasin. This implies that the greater the principal's leadership style, the better the quality of the teacher. Conversely, the lower the principal's leadership style, the less the output of the teacher is. 2) In MAN 1 MusiBanyuasin, work motivation has a positive and significant effect on the performance of teachers. This implies that the greater the job motivation of the teacher, the higher the performance of the teacher. Conversely, the lower the motivation of the teacher to work, the lower the performance of the teacher. 3) The principal's leadership style and job encouragement have a huge influence on the success of teachers in MAN 1 MusiBanyuasin at the same time. The performance of the teacher of 37.2 percent was affected by the headmaster's leadership style variable and job motivation, while the remaining 62.8 percent were affected by other variables beyond the study model, such as variables of the work environment, discipline, work ethics, and other variables.

\section{References}

Yamin and Maisah's Martinis. 2010. Teacher Output Standardization. Echo Persada Pers. Jakarta:

Bukman Lian and others, 2001. The impact on work discipline of leadership and teacher work motivation. Admin, Leadership, and Instructional Supervision Journal. January-June 2021 Volume 6, No. 1, January-June 2021 (downloaded, 30 December 2020)

Setiyati. 2004. The influence on teacher performance in technology and vocational education of principal leadership, work motivation, and school culture, 22 (2) (downloaded, 30 September 2020)

Barnawi and Arifin Mohammad.In 2014.Professional Teachers' Performance. Yogyakarta: Media Ar-Ruzz. Arikunto. 2010. 010. Procedures for Research: A practical approach. Jakarta: CiptaRineka.

Kartono, 2010. Leadership and Management.Rajawali: Jakarta.

SupRYin, MH.dkk. 2004.School Management. Semarang: UPT MKK, State University of Semarang.

Kurniadin, Didin and Machali Imam.In

2014. Concepts and principles of curriculum management in Educational Management. Yogyakarta: Media Ar-Ruzz.

Sutomo. 2011. Management of Colleges, Semarang: Semarang State University UPT MKK.

Uno, from 2008.Profession of Education.Jakart: Planet Alphabetisation.

Hey, Danim, S. 2010. 010. A School Management New Vision. Jakarta: Earth Alphabetisation.

Hey, Danim, S. 2010. 010. A School Management New Vision. Jakarta: Earth Alphabetisation. 